\title{
FORMAL VALUES OF LAW WITH EMPHASIS ON RECENT CASE LAW OF THE TAXATION OF ATHLETES ${ }^{1}$
}

\author{
MICHAL LIŠKA ${ }^{2}$
}

\begin{abstract}
This contribution deals with the problem of taxation of athletes. The hypothesis of this paper is the question whether the tax rules governing the taxation of athletes fulfill the appropriate formal quality of the legal regulation (formal values of law) required in a democratic legal state or not? The methods used for answering this hypothesis are the analysis of the law and selected jurisprudence of the higher courts; a comparison of the legal position of the athletes in the Czech tax law with European soft law model. Throughout the paper, syntax procedures will be used to create partial conclusions for the purpose of the final thesis. Although the position of collective athletes is concerning the matter of tax expenditures surrealistic, nevertheless we can see deep rationality in the motives of Supreme Administrative Court. The hypothesis of the paper needs to be answered positively, the regulation of the taxation of athletes in its current form does not fulfill the formal values of law, especially it fails in the perspective of predictability. Therefore, who knows if the campaign of the courts against the tax rules, which are devoid of formal values, will not continue.
\end{abstract}

\section{Keywords}

Taxation of athletes; formal values of law, income tax

JEL Classification: K34, H71, Z23

\section{Introduction}

Tax law is connecting every individual in the state and through the duty to assess taxes is, on the one hand, realized the will of the people to secure the running of

1 This article is the outcome of the research projects: MUNI/A/1359/2016 (Reformation of income taxes).

2 Postgraduate student at the Faculty of Law, Masaryk University at the Department of Financial Law and Economic. The Author specializes in tax law. Contact email: michaliska@mail.muni.cz. 
their own state (in the most general idea), on the other hand, it faces the principle of democratic state where the majority opinion must prevail. Tax laws should primarily be conceived within a long-term social consensus. Otherwise, it becomes an instrument of the ruling - the instrument justifying the means. A practical application of unstable law always causes serious problems.

As an example, the taxation of professional sportsman performers (athletes) can be used. On 13 July 2017, the Supreme Administrative Court ruled that David Lafata, a former football representative, could claim a $60 \%$ flat-rate tax expenditures as a professional footballer (the Financial Administration hold the view that the athletes of collective sports are allowed to use only the 40 percent of lump-sum rate). The judgment in case Lafata was based on the leitmotif of the previous Supreme Administrative Court's judgment (Supreme Administrative Court: 2 Afs 16/2011), in which the court criticized the absence of precise legal regulation relating to the performance of professional sport. The case law pointed out one of the Czech nuisance - a very complicated and confusing legal tax regulation.

Nowadays, the issue of the taxation of athletes is elaborated particularly in decisions of regional courts and in three judgments of the Supreme Administrative Court, by academic environment the topic was subject of research of M. Radvan (2014: 6070), J. Morávek and M. Štefko (2013: 354-358), T. Sluka (2007: 199) and R. Vybíral (2013: 12-17). However, the hypothesis of the paper was not explicitly "touched" by anyone of them.

\section{Origin and Concept of Formal (Values of) Law}

"Everyone knows what the law is, but no one can define it satisfactorily" (Knapp, 1995: 42). R. Zippelius responds (characteristically to the contemporary attitude of society), in the introduction to his work Das Wesen des Rechts, to the idea of St. Augustine. He proclaims that "(to) discover the law in our world, we do not need to know the a priori definition of law at all" (Zippelius, 1997: 133). Does it right that the system tiding human beings to act somehow was not only discoverable but also define, respectively understandable, doesn't it? Human life is large, if not whole, pervaded and governed by law. According to classics, the law is writhed by an endless war between three pillars of law - purposes of law - justice, legal certainty and effectiveness/purposiveness (Radbruch, 2012: 31). In fact, the main struggle is led between the individual interests represented by justice and the public welfare represented by purposiveness in the form of an effective and reasonable arrangement of things to achieve general well-being (Radbruch, 2003: 216). Legal certainty, hand in hand with the proportionality test in ad hoc cases, balances this clash. 
The application of the test of proportionality in tax law is very limited (Constitutional Court Pl. ÚS 29/08) and so as the main arbitrator in the tilt between the justice of the interests of the individual and the general interest stays legal certainty. Legal certainty is based on the idea of the practical possibility of planning and anticipating the consequences of its future actions - generally speaking, human life (Raz, 1986: 434). Predictability in this purest form has been placed in law from time immemorial, yet the legal certainty itself is connected with the Rule of law. ${ }^{3}$ German legal philosophy and $19^{\text {th }}$-century theory that build solid future foundations for Rechstaat, i.e. the law realistically applicable and practically enforceable, puts emphasis on the formal quality of law from which the fairness of content of the law can be born.

For the purposes of this paper, Jhering's concept of formal law will be used. Formal values of law were considered to be an inseparable part of the democratic Rule of law state, because without these values the very existence of the law, especially its acceptance and applicability, would not be guaranteed (Jhering, 1887: 588). The law, for the purpose of staying law (normative system), contains some immanent (with its nature necessarily tied) values: order, predictability, freedom from arbitrariness, legal equality, legal security and legitimacy (Summers, 2013: 30).

These values are in "law in action" marginally mentioned for example by the Constitutional Court of Czech Republic in its last "tax judgment" (Constitutional Court Pl. ÚS 9/15), specifically in the thought sequence devoted to the proper form of tax regulations. Tax rules "should at the same time be sufficiently precise, intelligibility and applicable in practice (by both taxpayers and body od Financial authorities). The need for practical application of these rules is reflected in the fact that the characteristics of tax structural elements can be adequately typified and flatted by the legislator". Requirements put on law are inspired by the praxis of application of the laws. The aspect of the precise tax law is connected with the restriction of the form of law by principle nullum tributum sine lege. In practice, the intelligibility ${ }^{4}$ is secured by the principle in dubio pro mitius - the guardian of free will and human freedom senso largo. The last requirement is quite indefinite and rather unexplored by legal praxis, even though it is based on the very conditions for enforceability of law 5 .

3 Even the emperor Ferdinand I. used Latin proverb "Fiat iustitia, pereat mundus" in non-ironical robe.

4 The statement of matters of facto $f$ the lawmaker directly (excluding the necessity of inference or argument to arrive at the meaning) and in such appropriate terms, so arranged, as to be comprehensible by a person of common or ordinary understanding.

5 The applicability of law in practice is based on the condition of the Rule of law formed by the will of the majority. If the law was not applicable in practice, it is not "usable" law, and not only for the impossibility of actually carrying out the imposed obligations but above all for the socially unacceptable of the nature of its content. 


\section{Taxation of Athletes in the Czech Republic and UEFA Model}

The Income Tax Act was created in former times when Czechoslovakia was still existing $^{6}$, but its constant changes led to the current state which is best described in the first sentence of the summary and evaluation of the facts of the Supreme Audit Office presented after inspecting aspects of the income tax of natural persons: "The Income Tax Act is unclear..." (Supreme Audit Office: 2017). On the example of the taxation of athletes can be seen how far the possible consequences of the lack of clarity of the law and strong judicial fight against this uncertainty can go.

The taxation of athletes in the European context has very clear outlines. An athlete is an employee of the club. As a textbook example of European standards, we can use Memorandum of Understanding between the Union des Associations Européennes de Football and the Fédération Internationale des Associations de Footballeurs Professionnels "FIFPRO Division Europe" (hereinafter "Memorandum") (Memorandum: 2007).

By the Memorandum on the one side, the club is obliged to ensure salary; other benefits; medical and health insurance for accident and illness; pension fund/social security costs; reimbursements for expenses incurred by the player; paid leave (holidays) $^{7}$ or mandatory insurance coverage for the player for illness and accident and regular medical/dental examination as well as medical/dental treatment with qualified personnel during football duties. On the other side the player is obliged to play matches to the best of his best ability, when selected; participate in training and match preparation according to the instructions of his superior; to maintain a healthy lifestyle and high standard of fitness; comply with and act in accordance with club officials' instructions (reasonable; e.g. to reside where suitable for the club); attend events of the club (sporting but also commercial ones); obey club rules (including, where applicable, club disciplinary regulations, duly notified to him before signing the contract); abstain from participating in other football activities, other activities or potentially dangerous activities not prior approved by the club and which are not covered by clubs' insurance; take care of the property of the club and to return it after termination of the contract; immediately notify the club in case of illness or accident and to not undergo any medical treatment without prior information to the club's doctor (except in emergencies) and to provide a medical certificate of incapacity; not to bring the club or football into disrepute (e.g. media statements); not to gamble or undertake other related activities within football and others.

6 There was a broad public consensus on the creation of basic laws and so their legitimacy is very strong.

7 The minimum is four weeks in each 12- month period. Periods of paid leave must be agreed by the Club in advance and must be taken outside the regular football season. It has to be ensured that at least two weeks are taken consecutively. 
The standardization regulation of the relationship between the player and the employer shows typical signs of dependent work (Liška, 2016: 103-126). The laborlaw protection of athletes in Europe even goes far beyond the protection provided in labor-law relations in the Czech Republic.

The independent work of dependant professions is connected with the misclassification of employees as independent contractors in the Czech legal system, which is a very simplified way supports dependant form of the work as the default form of work. It aimed to maintain the labor-law protection of dependent person against the employer's (cooperators) will.

However, mentioned default setting of the Czech labor-law system (and also taxlaw system) are colliding with tax-law jurisprudence which prefers the "mutual expression of the parties' will" over the content of the contract (material truth) (Šimka, 2014: 6-13). In the legal practice of taxation of athletes, the text of the law has been "bridged" 8 by the mutual expression of will through the "court complaint" against the lack of clarity of the legal regulation (Supreme Administrative Court 2 Afs 16/2011). The Supreme Administrative Court, while leaving the untouched contractual protection of athletes, carries out all the tax-law costs associated with the provision of this protection to the athlete, including "business risk", which is also covered by contract clauses and are typical for labor-law protection connected with the taxation of that dependent work. The only logical explanation for the above mentioned is the lack of formal qualities of tax-law regulation which considers the athlete to be subjects of dependent activity under Sec. 6 of the Income Tax Act.

\section{Formal Values of Law the Case of Income Tax Act v. the People}

The lack of clarity of the legal regulation of the taxation of athletes according to the Supreme Administrative Court (Supreme Administrative Court 2 Afs 16/2011) results from the factual absence of a private-law cause (economic reason) of taxation. Athletes are unclear employment/business category in the civil law and law generally. The Court's approach to the taxation of athletes is based on the following: If you, legislator, do not regulate this, we will accept the tax entity's interpretation, if it is interpretatively achievable. ${ }^{9}$ After the intervention of the court, the legislator has always the choice: he will adjust the certain area or impliedly agree with the opinion of the court, so he will leave the regulation in its current state. In the case of athletes, the Czech legislator approached the second option.

\footnotetext{
8 Although the Income Tax Act does not explicitly mention the taxation of athletes, it is necessary to take into account the material characteristics of the activity.

9 Bounds and interpretative limits of principle in dubio pro liberate. Cf Kokeš and Pospišil, 2009: 312.
} 
Formal values of the Income Tax Act have been questioned, in addition to the aforementioned Supreme Audit Office, by the Constitutional Court in the judgment concerning the VAT control statement, where, among other things, court reminded that the form submission ${ }^{10}$ has no support in the law, respectively requisites of the form are formulated so much widely (the prescribed data necessary for tax administration) that they are unpredictable to the taxpayer.

The taxation of athletes is also related to the predictability of taxation itself. In the case law (Supreme Administrative Court 6 Ads 88/2006) as well as in the legal theory of public law, great emphasis is placed on the predictability of law in the form of the existence of steady administrative practice consisting in the application, respectively non-application of law in a certain way. ${ }^{11}$ If the application is connected to a change in the view on the taxation of a particular subject(s), it is always advisable to ask the question whether this sudden change is predictable or not, respectively made in a predictable manner. For example, in connection with the imposition of a surcharge that is within the meaning of the Court's of Justice of the European Union case-law a criminal sanction (European Court of Human Rights 7356/10), it is always necessary to keep in mind that the requirements of Art. 7 of the Convention are fulfilled only and only if the national regulation of the crime is foreseeable, what means that an individual must be able to meet the meaning of the relevant provisions and to foresee the consequences of its breach (European Court of Human Rights 37571/97; European Court of Human Rights 17862/91 or European Court of Human Rights 32492/96; 32547/96; 32548/96; 33209/96 and 33210/96). Therefore, blank spaces of the law must always be colored before application, either green or red.

\section{Reasons for Additional No-Taxation of Athletes}

It was stated at the beginning that the courts found that in Czech law the taxation of athletes is not clearly defined. This consideration should be enriched by the fact that athletes were not mentioned in the explanatory note to fill out the forms of the tax return, nor was the issue mentioned in the official statement of any of the credible representatives of the "fiscal system". There was no D-instruction before the action "additional taxation of athletes" and the sanction did not meet criteria created by the pan-European principle nulla poena sine lege certa (Klip, 2011: 69). ${ }^{12}$

10 The only form of filing a tax return on the income tax of natural and legal persons acceptable by Financial administration.

11 This creates a law in the material sense (see: Kühn, 2016: 205-213).

12 In the case C-308/06 Intertanko general advocate says: The principle of legal certainty requires, in particular, that rules should be clear and precise, so that individuals may ascertain unequivocally what their rights and obligations are and may take steps accordingly. In connection with criminal offences and penalties it is given concrete expression by the principle of legality (nullum crimen, nulla poena sine lege) [...] This principle implies 
Taxpayers who self-assessing tax-law regulations are common people ${ }^{13}$ to whom the legislator, in part as well as the executive power ${ }^{14}$, has a duty. Duty to create a comprehensible, certain and practically applicable system of rights and obligations. ${ }^{15}$ In the area of the taxation of athletes, state representatives failed in fulfilling abovementioned requirement, even after prior notice by the judicial power.

\section{Some (Unintended) Effects of the Judicial Change of the Taxation Régime}

The taxing of athletes as independents contractors finds justification in formal values of law and their place in Czech tax entropy. However, if the court is going against the profiscal meaning of the law, even for the sake of protection of individuals, the difficulties in the legal application of the issue arise. In the Czech income taxes, troubles are always more or less connected with flat-rate tax expenditures.

Flat-rate tax expenditures have been for a long-term grateful topic in the Czech Republic for political and scientific discussion (Macháček, 2010: 288; Pelc, 2011: 204). Flat-rate tax expenditures could be described as averaging of real expenditures spent in the performance of a certain non-dependent activity in the form of legal fiction. In a case where a typically dependent activity, such as professional football, "reach for" flat-rate tax expenditures, absurd situations can occur.

The $40 \%$ or $60 \%$ tax expenditures covering the same expenses twice, although the expenses have been spent only by one of the contractual party (the player or the club). The player fictitiously uses them for jerseys, air tickets, trainers, masseurs, etc., but in fact, these services are paid by the club. Of course, the situation is related to the wrong wording and setting of the law that does not foresee this situation, since the application of flat-rate tax expenditures is not connected with the obligation to save an audit trail. So there is a place for application of one expenditure twice, respectively by two taxpayers.

that legislation must define clearly offences and the penalties which they attract. That condition is met in the case where the individual concerned is in a position, on the basis of the wording of the relevant provision and with the help of the interpretative assistance given by the courts, to know which acts or omissions will make him [...] liable.

13 In connection with the predictability is talked about criterion the prudent trader (see Court of Justice of the European Union 52/81 or Court of Justice of the European Union 74/74).

14 At this point is no choice but to recall the words of Radbruch: "The will of the lawmaker is not a method of interpretation, but rather the goal of interpretation and the result of interpretation, the expression for an priori indispensability of a systemic concordant interpretation of the whole legal system. It is for that reason possible to declare as the intention of the lawmaker something which was never present as the conscious will of the author of the law. The interpreter must understand the law better than did the person who created it; the law can be wiser than its author - it really must be wiser than its author" (Radbruch, 2003: 107). 
The past praxis, related to the first decision on the taxation of athletes, has created a sort of status quo. Collective athletes "fell to" a flat-rate of $40 \%$, an individual to a flat-rate of $60 \%$. This has solved the ills of diametrically different levels of the real costs of collective and individual athletes, but it is no longer actual nowadays (Radvan, 2017). To what extent new praxis is more likely similar to reality is at the discretion of each of us.

Successive amendments to the Income Tax Act caused that in the Czech Republic was set insurmountable upper rate of the flat-rate tax expenditures to CZK 1,200,000 per year, which particularly limits the possibility of double application of the flatrate expenditures.

\section{Conclusions}

The tax law should be the most transparent branch of law. It should typify the situation, clearly state the reasons for amendments and the sense and purpose of the legal regulation, be helpful and punish the violation of a predictable, intelligible and certain text of the law, not to remain silent and actively "manifest new interpretative view" within the control action - athletes 007 or others. The law has to be adherence, but it must be the law with all its material and formal requirements. The taxation of athletes is unregulated area and there is some open space for taxpayers (athletes) to choose a tax regime limited by an electric fence in the form of a clear text and meaning of the law.

In its decisions on the taxation of athletes, the Supreme Administrative Court forces the legislator to make detailed regulation for many types of occupations that are not regulated by law yet. This requirement is totally meaningless and in the Author's opinion it is enough if the executive power sufficiently specifies the subject matter of taxation in the form of the D-instruction, the Decree of the Ministry or other legitimate expectation ensuring way.

Although the position of collective athletes is concerning the matter of tax expenditures surrealistic, nevertheless we can see deep rationality in the motives of Supreme Administrative Court. ${ }^{16}$ The hypothesis of the paper needs to be answered positively, the regulation of the taxation of athletes in its current form does not fulfill

16 Professional sport is a profession that can be performed only for a limited time. It is a lifelong affair fitted into childhood and productive age. It goes without saying that athletes have to secure themselves for the future in the sport-productive part of their lives. If one day the postman knocked on his door and handed him the Financial administration's call, in which the Financial administration would demand his life savings, the decision is on the human side more than okay, even though purely theoretically the author cannot identify with it (Cf Liška, 2016: 103-126). 
the formal values of law, especially it fails in the perspective of predictability. ${ }^{17}$ Therefore, who knows if the campaign of the courts against the tax rules, which are devoid of formal values, will not continue. ${ }^{18}$

\section{References}

Jhering, R.: Der Zweck im Recht (Purpose in law), Leipzig: Breitkopf \& Härtel,1887.

Klip, A.: Substantive Criminal Law of the European, Antwerpen, Apeldoorn, Portland: Maklu, 2011.

Knapp, V.: Teorie práva (Theory of law), Praha: C.H. Beck, 1995.

Kokeš, M., Pospíšil, I. et al.: In dubio pro libertate. Úvahy nad ústavními hodnotami a právem. Pocta Elišce Wagnerové u př́ležitosti životního jubilea (In dubio pro libertate. Reflections on constitutional values and law. Tribute to Elizabeth Wagner on the occasion of the jubilee), Brno: Masarykova Univerzita, 2009.

Kühn, Z.: Správní řád a problematika ustálené správní praxe. (Administrative Act and the issue of steady administrative praxis), in: Rajchl, J. et al.: Správní řád - 10 let v praxi (Administrative Act - 10 years in praxis), Praha: Univerzita Karlova, 2016.

Liška, M.: Švarcsystém (Misclassification of employees as independent contractors), in: Radvan, M. et al.: Důchodové daně (Income tax), Brno: Masarykova Univerzita, 2016.

Macháček, I.: Daň z př́ijmů fyzických osob 2010. Praktická pomůcka k daňové optimalizaci (Income tax of natural person 2010. Practical guide to tax optimalization), Praha: C.H. Beck, 2010.

Memorandum of Understanding between the Union des Associations Européennes de Football ("UEFA") and the Fédération Internationale des Associations de Footballeurs Professionnels ("FIFPro") "FIFPRO Division Europe", 2007. www.uefa.com.

Morávek, J., Štefko, M.: Profesionální sportovci v kolektivních sportech (Professional athletes in colective sports), Časopis pro právní vědu a praxi (Jurnal for legal science and praxis) vol. 21, no. 3 (2013).

Pelc, V.: Daňové odpisy (Tax depreciation), Praha: C.H. Beck, 2011.

Radbruch, G.: O napětí mezi účely práva (About tension between purposes of law), Praha: Wolters Kluwer, 2012.

Radbruch, G.: Rechtsphilosophie (Philosophy of law), Heidelberg: C.F. Muller Juristischer Verlag, 2003 .

Radvan, M.: Lafatova daňová klička by neměla být přípustná (Lafata tax trick should not be allowed), 2017. www.ceskapozice.lidovky.cz.

Radvan, M.: Sportovci v kolektivních sportech (Professional athletes in collective sports), in: Radvan, M. et al.: Vybrané aspekty př́mých daní a jejich interpretace a aplikace v judicature (Selected aspects of income taxes and their interpretation and application in case law), Brno: Masarykova Univerzita, 2014.

17 Moreover, the tax surcharge imposed on the additional income tax of professional athletes would be in contradiction with European Charter of Human Rights.

18 A new Income Tax Act is currently being prepared. 
Raz, J.: The Morality of Freedom Clarendon, Oxford: Clarendon Press, 1986.

Šimka, K.: Švarcsystém v judikatuře Nejvyššího správního soudu (Misclassification of employees as independent contractors in Supreme Administrative Court case law), Bulletin Komory daňových poradců ČR (Bulletin of the Chamber of tax advisers CZ), no. 4 (2014).

Sluka, T.: Profesionální sportovec: právní a ekonomické aspekty (Professional athlete: legal and economic aspects), Praha: Havlíček Brain Team, 2007.

Summerts, R.S.:. Essays in Legal Theory, Dordrecht, Boston, London: Kluwer Publishing, 2013.

Vybíral, R.: Analýza judikatury vztahující se $\mathrm{k}$ postavení profesionálních sportovců $\mathrm{v}$ oblasti kolektivních sportů v České republice (Analysis of the case law relating to the position of professional athletes in the area of collective sports in the Czech Republic), Jurisprudence no. 1 (2013).

Zippelius, R.: Das Wesen des Rechts (Essence of law), München: C.H. Beck, 1997.

Court of Justice of the European Union: case CNTA v. Commission.

Court of Justice of the European Union: case B.N.O. Walrave, L.J.N. Koch v. Association Union cycliste internationale, Koninklijke Nederlandsche Wielren Unie a Federación Española Ciclismo.

Court of Justice of the European Union: case Christelle Deliège v. Ligue francophone de judo et disciplines associées ASBL.

Court of Justice of the European Union: case Gaetano Donà v. Mario Mantero.

Court of Justice of the European Union: case Intertanko vs Secretary of State for Transport.

Court of Justice of the European Union: case Union royale belge des sociétés de football association ASBL v. Jean-Marc Bosman.

Court of Justice of the European Union: case Faust v. Commission.

European Court of Human Rights: case Cantoni v. France.

European Court of Human Rights: case Coeme and others v. Belgium.

European Court of Human Rights: case Lucky Dev v. Sweden.

European Court of Human Rights: case Veeber v. Estonia.

CZ: Supreme Administrative Court: 2 Afs 16/2011/78.

CZ: Supreme Administrative Court: 6 Ads 88/2006/132.

CZ: Constitutional Court: Pl. ÚS 29/08.

CZ: Constitutional Court: Pl. ÚS 9/15.

Supreme Audit Office conclusion of control action 16/21, 2017. www.nku.cz/assets/kon-zavery/ k16021.pdf. 